\title{
Education, numeracy, and literacy: Baseline findings
}

Population Council

Follow this and additional works at: https://knowledgecommons.popcouncil.org/departments_sbsr-pgy

Part of the Demography, Population, and Ecology Commons, Family, Life Course, and Society Commons, Gender Equity in Education Commons, International Public Health Commons, and the Maternal and Child Health Commons How does access to this work benefit you? Let us know!

\section{Recommended Citation}

"Education, numeracy, and literacy: Baseline findings," AGEP brief. Lusaka: Population Council, 2015. 
The Adolescent Girls Empowerment Program (AGEP) is a program for girls ages 10-19 in rural and urban Zambia that aims to find the best ways to improve their social, health, and economic resources. The program involves over 10,000 girls participating in weekly girls' group meetings, receiving health vouchers and opening savings accounts. Over 5,000 girls, unmarried at baseline, are enrolled in a randomized, controlled trial and are being followed over four years-including the two years of the program and two years after. This brief describes the characteristics of these girls at baseline.

\section{INTRODUCTION}

Education is a critical component of a healthy transition to adulthood. During adolescence, young people develop physical and cognitive skills and acquire the knowledge and information necessary to becoming healthy, productive adults. Providing quality education in a safe environment and keeping children in school is a cross-cutting strategy that improves multiple health outcomes. For example, being in school has been associated with delays in the age at first sex, marriage, and childbearing. When comparing in-school to out-ofschool girls of the same age, in-school girls are less likely to have had sex, and, if they are sexually active, are more likely to be using contraceptives. The risk of school dropout increases for girls who have had premarital sex. (Lloyd, 2008)

However, in both rural and urban settings in Zambia, disaggregated data from the Demographic and Health Survey (ZDHS) show that girls have lower levels of school enrollment than boys in the respective setting. Furthermore, school enrollment levels for girls in urban

- For both urban and rural girls, school dropout begins at age 13.

- One-third of girls ages 10-14 in Zambia are already off course with their schooling-meaning that they have either never been in school, are not currently in school, or are in school but more than two-years behind grade-for-age.

The Population Council conducts research and delivers solutions that improve lives around the world. Big ideas supported by evidence: It's our model for global change. popcouncil.org 
- $30 \%$ are three or more years behind.

- In both rural and urban areas and at each age level, girls are consistently behind in the expected number of years of schooling to be completed. The gap increases as girls move into older adolescence
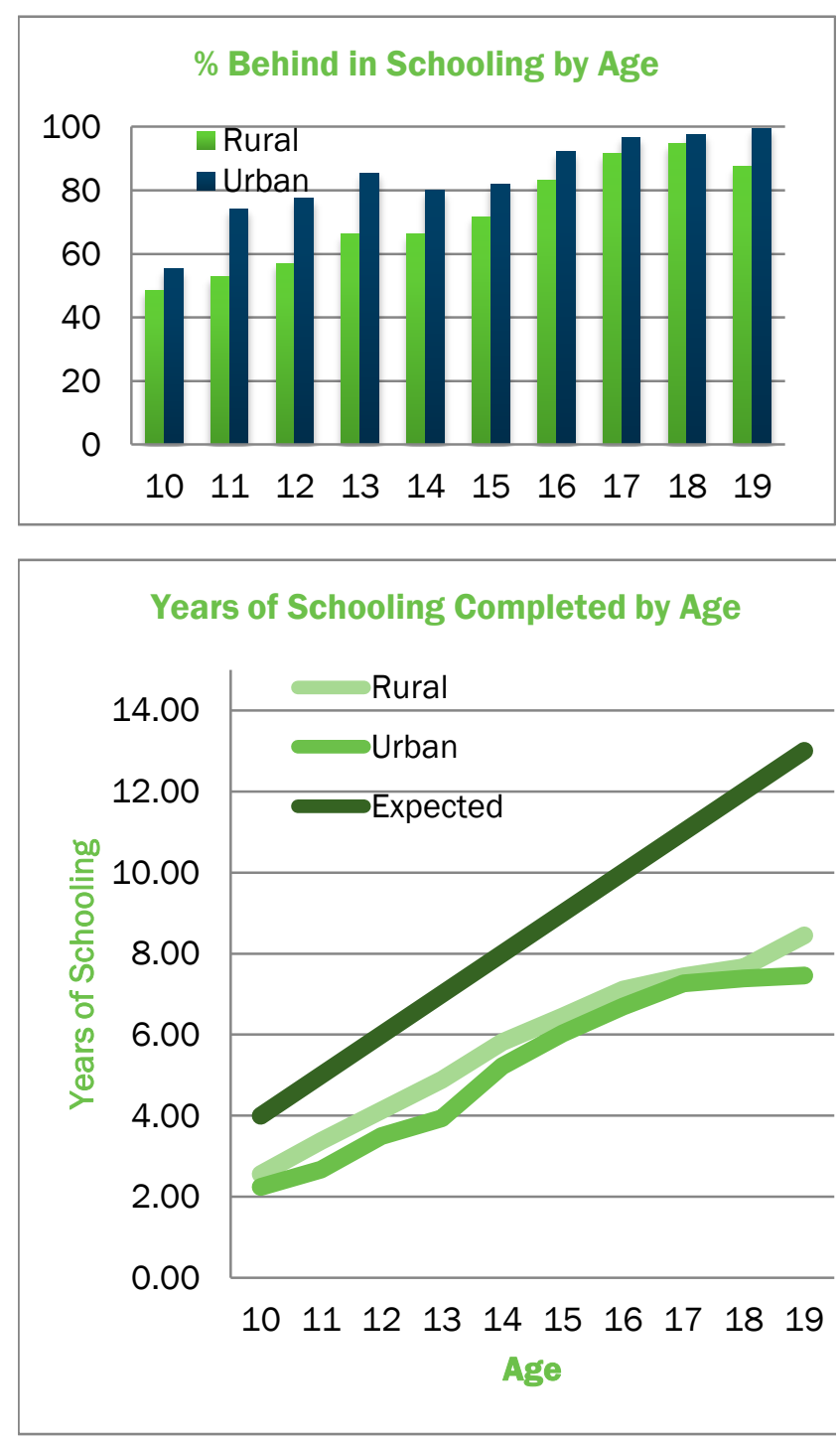

\section{Reasons for school leaving}

The two most common reasons given by girls in the AGEP sample for dropping out of school were financial reasons \& pregnancy. Across all segments, financial reasons represented the most common response, while pregnancy was more prominent among the older cohort. Poor school performance and not liking school/rather be doing something else were then next most common reasons.

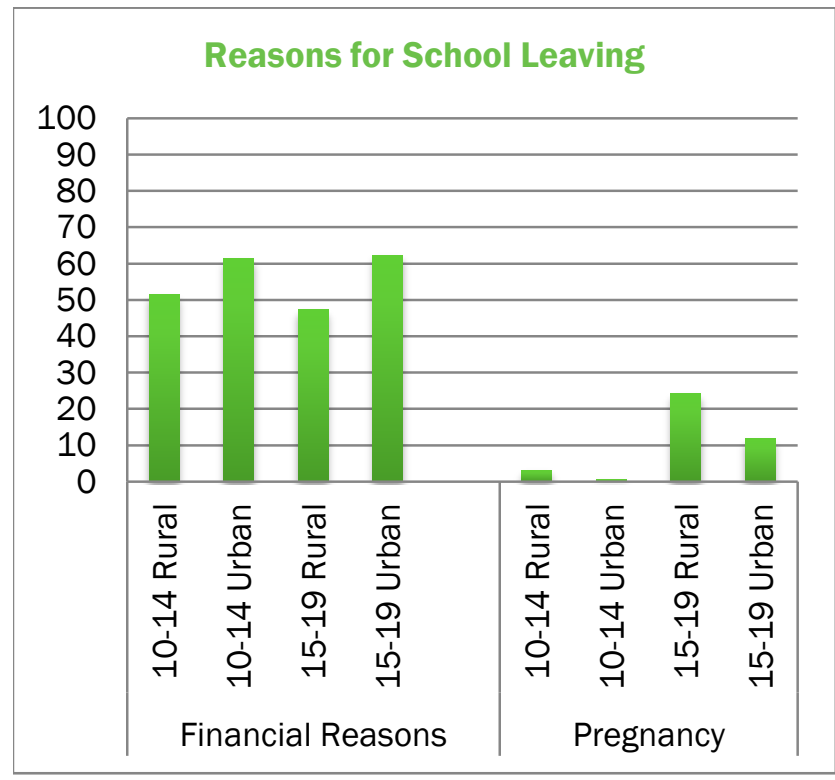

- When asked about the most common reasons for being absent from school, being sick/ill, tending to household responsibilities and having a dirty uniform were the most common responses. Being sick represented the large majority of reasons for absenteeism for all groups.

- Only $1 \%$ of girls in the AGEP sample stated that menstruation was a reason for missing school.

\section{Literacy and numeracy}

Overall levels of literacy are quite low, with less than a third of younger girls and about half of older girls being able to read.

- When looking at literacy levels by number of years of schooling attained, it appears that only in secondary school do girls starting developing meaningful literacy skills.

- Math skills are also low. Out of a maximum of 10 possible correct answers meant to be completed by those with four years of schooling, not even those with secondary school could complete more than $75 \%$ Results are similar for girls in both urban and rural areas.

This program is funded by UKaid from the Department for International Development.

\section{CONTACT INFORMATION}

For more information about AGEP, call +260 211295925

or email agep@popcouncil.org

or visit: http://www.popcouncil.org/research/ adolescent-girls-empowerment-program
Population Council

Plot \#3670 No. 4 Mwaleshi Road

Olympic Park

Lusaka, Zambia 10101 